\title{
Ölmez Ağaçtan "Ah'lar Ağacı"na: Türkiye'de Zeytin Ağaçlarının Devinimi
}

\author{
Orkun Doğan*
}

\section{Özet}

Bu yazı odağına bir Akdeniz müştereği olarak tanımlanacak zeytin ağacını alarak zeytin ağaçlarının son yıllarda Akdeniz'de, zeytinin anavatanı olarak sayılabilecek Anadolu'daki devinimini inceleyecektir. Bir coğrafyaya referansla izi sürülecek devinim, sadece bir nesnenin —zeytin ağacının, zeytinin veya zeytinyağın— fiziki anlamda yer değiştirmesi üzerinden düşünülen hareketinin ötesinde farklı anlamlarla ele alınacaktır. Zeytin ağaçlarının ekonomik bir faaliyetin konusu olmasıyla farklı üretim tarzları altındaki örgütlenişi, emek ve mülkiyet ilişkilerinde yaşanan dönüşüme bağlı bir devinimine işaret etmektedir. Bu yazıda, Türkiye'de 2000 yılı sonrasında zeytin ağaçlarının konu olduğu bu çatışmalı ve çok boyutlu devinim süreci eleştirel olarak incelenecektir. Devinim kavramı ile zeytin ağaçlarının insani faaliyetler sonucunda yerinden edilmesinin ötesinde, zeytinin siyasetinin, ekonomisinin ve ekolojisinin toplumsal değişim içerisinde geçirdiği dönüşüm kastedilmektedir. Son yıllarda Anadolu'da zeytin ağaçlarını yerinden eden söylem ve pratiklerin karşısında zeytinlikleri ve zeytin ağaçlarını yeniden bir müşterek olarak ele alan alternatif bir siyasetin imkânları tartışılacaktır.

Anahtar sözcükler: Zeytin ağacı, Akdeniz, devinim, hegemonya, müşterekleştirme

\section{Abstract}

From The Tree of Life to the Tree of Lament: The Motion of Olive Trees in Turkey

This paper focuses on olive tree as a Mediterranean common and examine the recent mobility of olive trees in Anatolia, the homeland of the olive tree. The paper regards the term motion, which is traced in a specific geography, as denoting more than the spatial movement of an object, such as olive tree, olive or olive oil. The subjection of olive trees to economic activity and their organization under different modes of production indicate a motion depending on the transformation in labor and property relations.

This paper critically examines the conflictual and multi-dimensional motion of olive trees in Turkey since the year 2000. The paper traces, in addition to the displacement of olive trees as a consequence of human activities, the transformational dynamics of olive politics, olive economy and olive ecology through social change.

In conclusion, the paper discusses the possibility of an alternative politics that relocates olive groves and olive trees as a commons against the destructive discources and practices of authoritarian developmentalism that have led to the displacement of olive trees in Anatolia in recent years.

Keywords: Olive tree, Mediterranean, motion, hegemony, commoning

* İstanbul Bilgi Üniversitesi, Ekonomi Bölümü 


\section{Giriş}

“...Yaşamak sadece sevmektir, inan bana.

Sevmeyenler dünyamızda yaşamıyor.

Yaşamak suda, toprakta, insanlarda görünerek;

bir zeytin ağacı gibi.

Bir zeytin ağacı gibi, ne güzel denize yakın olacaksın,

uzayan dallarında, yapraklarında ışık ta derinlerde köklerin.

Bir zeytin ağacı gibi, bin yıl severek yaşamak her gün..."1

Bu yazı odağına bir Akdeniz müştereği olarak tanımlanacak zeytin ağacını alarak zeytin ağaçlarının son yıllarda Akdeniz'de, zeytinin anavatanı olarak sayılabilecek Anadolu'daki devinimini inceleyecektir. Bir coğrafyaya referansla izi sürülecek devinim, sadece bir nesnenin -zeytin ağacının, zeytinin veya zeytinyağın - fiziki anlamda yer değiştirmesi üzerinden düşünülen hareketinin ötesinde farklı anlamlarla ele alınacaktır. Zeytin ağaçlarının ekonomik bir faaliyetin konusu olarak farklı üretim tarzları altındaki örgütlenişi, emek ve mülkiyet ilişkilerinde yaşanan dönüşüme bağlı farklı bir devinimine işaret eder. Zeytin ağaçlarının, devletin veya farklı çıkar gruplarının kalkınma stratejilerinin hedefi olarak veya hukuki anlamda özel mülkiyet rejiminin, kamu yararı ve çevre korunma gibi kavramların öznesi olması, bahsedilen bu devinimin şiddetinin ve yönünün çatışma ve müzakereler içerisinde belirlenmesi anlamına gelir. Devinim kavramı ile zeytin ağaçlarının insani faaliyetler sonucunda yerinden edilmesinin ötesinde, zeytinin siyasetinin, ekonomisinin ve ekolojisinin toplumsal değişim içerisinde geçirdiği dönüşüm itibariyle insan-zeytin ilişkisinin değişen mahiyetine de atıfta bulunacaktır. Bu yazıda, Türkiye'de 2000 yılı sonrasında zeytin ağaçlarının konu olduğu bu çatışmalı ve çok boyutlu devinim eleştirel olarak incelenecektir.

Yazının ilk bölümünde zeytin ağacının ve zeytincilik bilgisinin Akdeniz dünyasında tarihsel hareketi anlatılacaktır. Akdeniz(lilik) denen tahayyülün temel öğesi olan zeytin kültürünün nasıl şekillendiği, Akdeniz insanının zeytinle, zeytinin Akdeniz insanı ile tarihsel süreçte nasıl bir ekoloji ve kültür coğrafyası oluşturduğu takip edilebilecektir. Sonraki bölümde, zeytin ağaçlarının yakın geçmişte Anadolu coğrafyasındaki hikayesine odaklanılacaktır. Tarım sektöründe yaşanan zeytincilik seferberliği, Türkiye'nin 2000 sonrası kalkınma ve çevre politikalarının dönüşümüne paralel bir şekilde incelenecektir. Bu çatışmalı sürecin zeytin ağaçları ve zeytincilik alanında faaliyet gösteren farklı aktörler nezdindeki yansımaları tartışılacaktır. Son olarak, son yıllarda Anadolu'da zeytin ağaçlarını yerinden eden söylem ve pratiklerin karşısında zeytinlikleri ve zeytin ağaçlarını yeniden bir müşterek olarak ele alan alternatif bir siyasetin imkânları tartışılacaktır.

1 Arif Damar, “Her Gün Yaşamak”, Yoksulduk Dünyayı Sevdik içinde (İstanbul: Kırmızı Yayınlar1, 2007), 94. 


\section{Bir Akdeniz Müștereği olarak Zeytin Ağacı}

"Zeytin ağacının vazgeçtiği yerde Akdeniz biter." ${ }^{2}$

Zeytin, ağacıyla, meyvesiyle, yağıyla ve bunların etrafında kurulan tarih boyunca insan-doğa ilişkisinin izleğini sürmeyi mümkün kılan kültürü ile Akdeniz uygarlığının ayrılmaz bir parçasıdır. Arkeobotanik çalışmalar göstermektedir ki Akdeniz iklim kuşağının tipik bitki örtüsü olan makilerin bir üyesi olan yabani zeytin ağacı ilk olarak Doğu Akdeniz'de var olmuştur. Anavatanın tam olarak neresi olduğu ve ne zaman ilk olarak kültür altına alındığı hususunda farklı görüşler olmakla birlikte, ilk kez erken Bronz Çağı'nda (MÖ 3000-2000) bugün Suriye ve Filistin arasında kalan bölgede aşılanarak yetiştirilmeye başlandığ 1 tahmin edilmektedir. ${ }^{3}$ Kesin ve tartışmasız olan, zeytinin bir Akdeniz ağacı olduğudur. Zeytin ekolojisi tarihsel olarak doğudan batıya doğru yayılmıştır; Akdeniz'den iç bölgelere doğru sokulsa da bu yayılma iklim elverdiğince mümkün olmuştur. Zeytin ağacının zamanda ve mekânda bu yolculuğu, Akdeniz kültüründe hem kök salmasına, derinleşmesine hem de dallanıp budaklanmasına, yayılmasına ve zeytinin Akdeniz kültür coğrafyasının karakteristik bir öğesi haline gelmesine sebep olmuştur.

Fernand Braudel, Akdeniz'i florasıyla, topog rafyasıyla, kültürüyle ve ekonomisiyle geniş ve çok boyutlu tanımlar. Ona göre, Akdeniz'in sınırını çizen politik sınırlar değildir elbet; sınırı belirleyen ne tek başına iklimdir ne dağlardır. Akdeniz güneyde palmiye ağaçlarının, kuzeyde zeytin ağaçlarının gidebildiği, yaşayabildiği ve kök salıp gölge edebildiği yere kadar erişir. ${ }^{4}$ Zeytin yoksa Akdeniz de yoktur. ${ }^{5}$ Coğrafyacı Vidal de la Blache, İbn Haldun'a nazire edercesine, iklim ve bağlı olarak bitki örtüsünün insanların yaşam biçimlerini belirlediği ve bu sayede toplulukların birleştiğini ve birbirinden ayrıldığını ifade eder. Ona göre Akdeniz bir yerde başliyor ve bitiyor ise, bu coğrafyada insanlar buğday yetiştirdiler, koyun ve keçilerine baktılar, ağaçlardan zeytin ve incir topladılar ve yetiştirdikleri üzümlerden şarap ürettiler. ${ }^{6}$ Benzer bir tanımlama antropologlar tarafından mutfak ve yemek kültürü üzerinden yapılır: Avrupa'da kuzeyle güneyi ayıran bir başka boyut toplumların mutfaklarında ve sofralarında zeytinyağ 1 (şarap) ve tereyağ 1 (bira) tercihleridir. ${ }^{7}$ Gastronomik olarak Akdeniz

2 Georges Duhamel'den aktaran Maguelonne Toussaint-Samat, A History of Food (John Wiley \& Sons, 2009), 187.

3 Kathleen M. Kenyon, E. J. Moynahan ve J. D. Evans, "The Olive in the Mediterranean: Its Culture and Use [and Discussion]", Philosophical Transactions of the Royal Society of London. Series B, Biological Sciences 275, no. 936 (1976): 187.

4 W. V. Harris, "The Mediterranean and Ancient History", Rethinking the Mediterranean içinde, der. W. V. Harris (Oxford: Oxford University Press on Demand, 2005), 21-22.

5 İlhan Tekeli, “İzmir Tarihi'nin İçine Yerleştirilebileceği Bir Akdeniz Üst Anlatısı Üzerine”, Akdeniz Tarihi, Kültürü ve Siyaseti “Çoğulluğu ve Farklılı̆̆ İ̧eren bir Birlik Özlemi" Sempozyumu Bildirileri içinde, der. Alp Yücel Kaya vd. (İzmir: İzmir Akdeniz Akademisi, 2016), 145.

6 Vidal de la Blache'dan (1886) aktaran Paul Claval, Colette Jourdain-Annequin, "For Whom the Mediterranean Sea is 'Our Sea'?", Athens Journal of Mediterranean Studies 3, no. 2 (2017): 109.

7 Sara Delamont, Appetites and Identities: An Introduction to the Social Anthropology of Western Europe (Londra: Routledge, 1995), 20. 
hayali bir uzamı tanımlamaktadır: Kuzey'in ve temsil ettiği yemek kültürünün modernliği, işlenmişliği ve endüstriyelliği karşısında Akdeniz doğaldır, antiktir, bozulmamıştır, bakirdir. Böylesi bir Akdeniz temsilini kuran temel öğelerden bir de tabii ki zeytin ağacı ve zeytinyağıdır.

Medeniyetler arasındaki etkileşimlerin sonucu olarak sadece zeytin ağaçları taşınmamıştır farklı coğrafyalara, zeytinin bilgisi de ortaklaştırılmıştır. Zeytinin bilgisi, doğayla insanlar arasındaki metabolik ilişkinin belirlediği her türlü üretim, mübadele ve güç ilişkisinde vardır. Yabani zeytin ağaçlarının aşılanması, delicelerin taşınması, zeytin ağacının aralanması, meyvenin toplanması ve taşınması bilgisi zeytin ağacı kültüre alındığından bu yana farklı şekillerde üretilmekte ve birikmektedir. Zeytinyağı elde etmeye yönelik teknikler, zeytinyağından sabun yapılması, zeytinyağının muhafazası ve ticareti medeniyetler arasında taşınarak bugüne gelmiştir. Arkeolojik çalışmalar göstermektedir ki zeytin ağacının kendisi gibi onunla ilgili bilgi de Akdeniz coğrafyasında hem çok eski hem çok çeşitlidir. Zeytin ağacı gibi zeytinin bilgisi de taşındığı bölgenin ikliminden, toprağından ve de insanından etkilenmiş ve zaman içerisinde onlara adapte olmuş ve kendi yolunu bulmuştur. Özetle, zeytin ağacı kadar zeytinin bilgisi de Akdeniz'de müşterektir. ${ }^{8}$

Marx insan ve doğa ilişkisini organik bir ilişki olarak ele alarak, doğa ile insan emeğini metabolik bir ilişkisellik içinde değerlendirmeyi önerir. ${ }^{9}$ Yabani bir zeytin ağacının bir insan tarafından aşılanması ve kültür altına alınması insan için yeni bir olasılık evreni açar. Bugünden baktığımızda aksinin düşünülmesi zor da olsa doğa ve insan arasındaki ilişkisellik illa ki tek taraflı ve bir tahakküm ilişkisi olmak zorunda değildir. İnsanın yaşamını sürdürmek için ortaya koyduğu emek süreci, bu metabolik ilişkinin kurulduğu ve düzenlendiği süreçtir. Metabolizma kavramı burada bir karşılıklılık ifade etmektedir; hem toplumsal yaşamın ve zenginliğin üretiminde doğaca dayatılmış koşulları hem de insanların eylemleri ile doğal süreçlere etki edebilme kapasitesini kuşatan bir kavramsallaştırmadır. Doğanın bir parçası olan emek, üretim süreci içerisinde doğaya müdahale eder, onun bir parçası olması sebebiyle de hem onu değiştirir hem de kendi değişir. Karşılıklılığı (ön)varsayan doğa ve insan arasındaki bu metabolik ilişkiyi tarım devrimi olarak anılan süreç üzerinden yakalayabiliriz.

Viktor Hehn, kültür tarihi üzerine olan çalışmasında, yerleşik yaşama tarım ile değil, yabani ağaçların kültür altına alınması ve daha genelinde "ağaççılık" ile adım atıldığını iddia eder. Ağaç meyve verene kadar yıllarca bakılmak ve sulanmak ister, bu da tarımdaki dönemlik öngörünün çok ötesinde bir düzeni gerektirir. Sağlam bir siyasi düzeni özel mülkiyetin oluşumunu ve sulama sistemlerinin gelişimi için bir gereklilik olarak benzer bir şekilde ele alır. Zeytin ağaçlarının (ormanın) bir doğa manzarasından zeytinliklere (bahçeye) dönüşmesini bir kültür devrimi olarak anar. Bu manzaranın insanda kültür, huzur

8 Bkz. Artun Ünsal, Ölmez Ağacın Peşinde: Türkiye'de Zeytin ve Zeytinyağı (İstanbul: Yapı Kredi Yayınlar1, 2001), 37-111.

9 Lixin Han, "Marxism and Ecology: Marx's Theory of Labour Process Revisited", Eco-socialism as Politics içinde, der. Qingzhi Huan (Dordrecht: Springer, 2010), 23-24. 
dolu düzen ve bu düzenin sürekliliği duygusunu uyandırdığından bahseder. ${ }^{10}$ Zeytin ağacının bu anlamda en uzun devinimi 6000 yıllık olduğu varsayılan kültür altına alınmasının tarihidir. Kültür devrimi ile delicelerin ehlileştirilmesi, yabanilerin aşılanması, zeytin ormanlarının modern zeytinliklere dönüşmesi zeytin ağacının bitmeyen devinimidir. Modernizmin kartezyen dünyasında insanla zeytinin ilişkisi, bir aradalığı aşınmaya, doğanın fethi ile aradaki metabolik ilişki yarılmaya ve bir tahakküm ilişkisi şeklinde kurulmaya başlanmıştır.

Bu bölümde tarihsel süreçte insan ve zeytin arasındaki ilişkinin değişen niteliğini belirleyen bazı süreçlere işaret edilmiştir. Yazının kapsamı gereği bu süreçler soyut bir anlatı içerisinde tartışılarak zeytin ağaçlarının çok boyutlu devinimi hakkında düşünmemizi sağlayan bir çerçeve olarak sunulmuştur. Sonraki bölümde girişte tercih edilen anlatıdan kopmak pahasına bu devinimin somut analizine ve maddi koşullara vurgu yapmak amacıyla yazının odağ Türkiye'de 2000 yılı sonrasında zeytin ağaçlarının hikâyesine ve bu süreçte devinimlerini belirleyen siyasi ve ekonomik süreçlere kaydırılacaktır.

\section{Türkiye'de (Yeniden) Zeytincilik Seferberliği}

“Hiçbir şey zeytinliklerin görüntüsü kadar kültür, huzur dolu düzen ve bu düzenin sürekliliği duygusunu uyandıramaz içimizde. Demek ki manzara ve ağaç bir şeyler öğretebilir ama yalnızca doğa manzarası, kültür manzarasına dönüştüğünde." ${ }^{\prime 11}$

Türkiye'de zeytincilik, 2000'li yılların ortalarından bu yana uygulamaya geçirilen ve zeytin seferberliği olarak tarif edilen politikaların sonucunda yapısal bir dönüşüm süreci içerisindedir. Bu süre zarfında, tarımdaki dönüşüme paralel olarak birçok geleneksel ürün için gerçekleşen üretim alanlarındaki daralmanın tersine, zeytin ağacı varlığı ve zeytinlik alanlar hızlı bir şekilde artış göstermiştir. Öte yandan, zeytin ağacı sayısındaki artışa paralel olarak son yıllarda hükümetin kalkınma politikalarındaki tercihlerine bağlı olarak zeytin üretiminin yapıldığı farklı bölgelerde planlanan veya hayata geçirilen enerji üretimi, sanayi, madencilik veya turizm ile ilgili bazı yatırım projeleri sebebiyle birçok zeytin ağacının kesilmesi ve zeytinlik sahaların bu projelere tahsisi daha sık gündeme gelmektedir. Son yıllarda zeytin ağaçlarının konu olduğu ekolojik tahribatların yanı sıra, zeytin ağaçları ve zeytinlik alanlarla ilgili hukuki koruma mevzuatının değiştirilerek zeytin ağaçlarının yasa dışı olarak kesilmesini ve zeytin üretiminin zarar görmesini engelleyen hükümlerin değiştirilmesine yönelik hükümet nezdinde çeşitli girişimler olmuştur. Yaşanan tahribatlar ve yasal düzenleme girişimleri, bunlara karşı farklı bölgelerde farklı hassasiyetlerle ve taleplerle oluşan bazı yerel hareketlerin ve zeytin ağaçlarını ortak değer olarak kurgulayan bir toplumsal muhalefetin ortaya çıkmasına sebep olmuştur. Özetle, son 15 yıllık zaman zarfında Türkiye'de zeytin seferberliğinin, zeytin

10 Viktor Hehn, Zeytin, Üzüm ve Incir: Kültür Tarihi Eskizleri, çev. Necati Aça (Ankara: Dost Kitabevi Yayınlar1, 1998), 80.

11 Hehn, Zeytin, Üzüm ve İncir, 86. 
kesimlerinin, zeytin mücadelelerinin eş zamanlı olarak gerçekleştiği bir süreç yaşanmaktadır. Bu kısımda bu sürecin ekonomik, ekolojik ve toplumsal yansımaları, bu yazıda zeytin ağaçlarının devinimi olarak tarif edilen kavramsallaştırma üzerinden tartışılacaktır.

Türkiye'de 2000'lerle birlikte tarımda yaşanan yapısal dönüşüm ile birlikte birçok geleneksel ürün için gerçekleşen üretim alanlarındaki daralmanın tersine, zeytin ağacı varlığı ve zeytinlik alanlar hızlı bir şekilde artış göstermiştir. Bu gelişme sadece zeytin üretiminde yaşanmamış, zeytin ve zeytinyağı işleme sanayisine ve ticaretine olan ilgi artmış; farklı sektörlerden zeytincilik sektörüne ciddi sermaye aktarımları yaşanmıştır. Bu süreç iktidar ve süreci yöneten aktörler nezdinde "zeytin seferberliği" olarak anılmaktadır. ${ }^{12}$

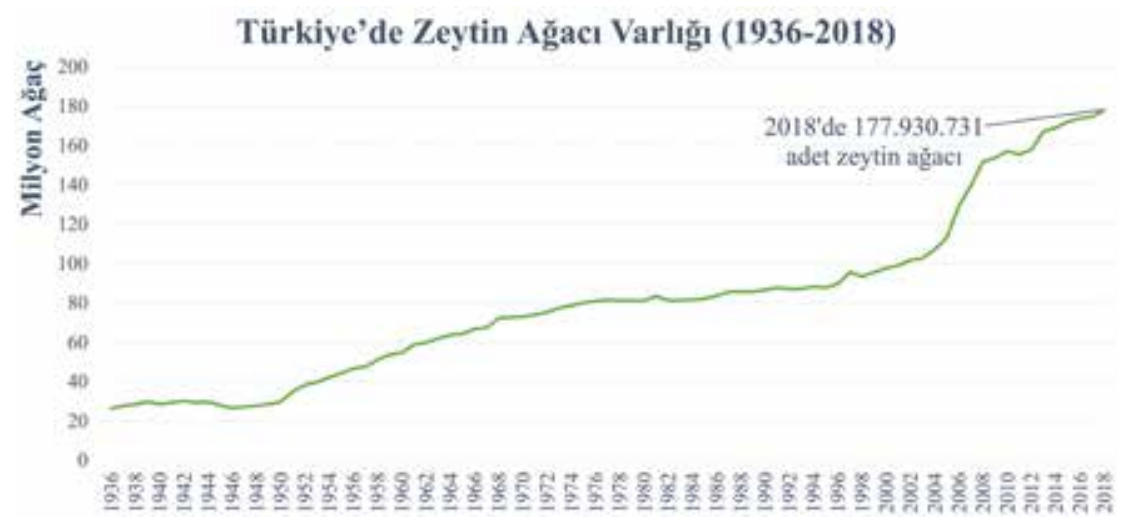

Grafik 1: Türkiye'de Zeytin Ağacı Sayısı (1936-2018). TÜİK ve Zeytin Dergisi (1960-1962) verileri kullanılarak yazar tarafından oluşturulmuştur.

\section{Zeytinciliğin Islahı ve Yabanilerinin Aşılattırılması}

Bu seferberlik söylemi iktidar ve zeytincilik sektöründe faaliyet gösteren aktörler tarafından tarihsel bir referansla sahiplenilmektedir. Cumhuriyetin ilk yıllarında zeytin ve zeytinyağı üretimi açısından modernleşme çabası olarak düşünülebilecek bir sürece gönderme yapmaktadır. O yıllarda mülkiyet rejiminde, ormanların yönetiminde ve tarım teşkilatında yapılan reformlar ve kurumsal yapılanmanın bir yansıması zeytincilik alanında da hayata geçirilmeye çalışılmıştır. Kalkınma politikalarına bağlı olarak bazıları sonraki yıllarda tasfiye edilecek olan, bazıları ise bugün de zeytincilik alanında faaliyet gösteren kamu kurumlarının temelleri bu dönemde atılmıştır. Zeytinliklerle ilgili bugün de geçerli olan hukuki mevzuat da yine bu dönemde oluşturulmuştur. Bu adımlarda kendini gösteren modernleşme çabası, bugün zeytin ağaçlarının yasadışı

12 Seferberlik askeri literatürde ülkenin silahlı kuvvetlerini savaşa hazır duruma getiren, ülkenin ekonomisini, yönetimini savaş gereklerine uyacak duruma sokan hazırlıkların ve önlemlerin tümü anlamına gelmektedir. Zeytincilikte konulan hedefler, bu hedefler doğrultusunda insan gücünün, finansmanın ve ekolojik varlıkların mobilize edildiği süreç düşünüldüğünde seferberlik terimi zeytincilikte benzer bir bağlama oturmaktadır. 
kesilmesiyle ilgili çok tartışılan ve ilk olarak 1939'da yasalaşan 3573 sayılı “Zeytinciliğin Islahı ve Yabanilerinin Aşılattırılması Hakkında Kanun"un (bundan sonra Zeytincilik Kanunu) özünü oluşturmaktadır.

Zeytincilik Kanunu'nun öncesinde Ziraat Vekaleti tarafından hazırlanan 1938 yılına ait "Zeytincilik, Ziraat, İstihsal ve İhracat Vaziyeti" başlıklı raporda zeytinciliğin o yıllardaki durumu belgelenmiş, zeytin ve zeytinyağı üretiminin ve kalitesinin arttırılmasına yönelik tavsiyelere yer verilmiştir. Raporda zeytinciliğin "1slah ve inkişafı" açısından mahsuldar zeytinliklerin verimini arttırılması ve yağ sanayinin teknik bir disipline tabi tutulması gerekliliği vurgulanmaktadır. Ayrıca, yabani zeytinliklerin (olduğu yerde) aşılanması, fidan ve dikme (yabani zeytin ağaçlarının taşınarak aşılanması) ile yeni zeytinliklerin tesis edilmesi tavsiye edilmektedir.

\begin{abstract}
Zeytin mahsullerinin ihzar ve istihsal işlerindeki rasyonalizasyonu kısa zamanda tahakkuk ettirerek bu mahsullerin iç ve dış piyasaların istediği tip ve şekilde istihsalde bulunmak ve aynı zamanda müstahsile gösterici ve başlattırıcı şekilde olmak üzere bazı organizasyonların kurulması lazımdır. Bu suretle iç ve dış piyasaların istediği muayyen yağ tiplerinin geniş ölçüde istihsalini tahakkuk ettirmeğe yarayacak rasyonel zeytin tasirhaneleriyle zeytin istandart ve imalathanelerinin tesisiyle mümkündür. ${ }^{13}$
\end{abstract}

Raporda belirtilen yabani zeytinliklerin aşılanması ve yeni zeytinliklerin tesisi hedefi Zeytincilik Kanunu'na, devlete ait sahalarda veya orman arazilerinde bulunan yabani zeytin ağaçlarının üreticiler tarafından aşılanarak üretken kılınması, bunun sürekliliğini sağlamak için de bu arazilerin üreticilere belirli şartlar karşılığında dağıtılması yani özel mülkiyete geçirilmesi hükümleri ile yansıtılmıştır. ${ }^{14}$ Zeytincilik Kanunu, özetle dönemin kalkınma söyleminde öne çıkan "ziraatta rasyonalizasyon ve sanayide teknik ıslahat" yaklaşımının zeytincilik alanına tercümesidir.

Zeytinciliğin ıslahı-modernleştirilmesi, tarımda kapitalist gelişme süreci içerisinde, bir hedef olarak kalmış, tamamlanamamış bir projedir. Bazı dönemlerde, zeytin ve zeytinyağı piyasasında güçlü olan bazı aktörlerin ve bürokratların ortak çabalarıyla bu amaca yönelik politikalar ve uygulamalar devletin kalkınma öncelikleri arasına girmişse de, birçok zeytin üreticisinin zeytin ve zeytinyağı üretimini ikinci bir uğraş, ek gelir getiren bir faaliyet olarak görmesi gibi, yönetenlerin de zeytinciliğe tarımda öncelikli bir sektör olarak yaklaştığını söylemek zor olacaktır. Cumhuriyet tarihi boyunca, ne alelumum delicelikler

13 T.C Ziraat Vekaleti, “Zeytincilik, Ziraat, İstihsal ve İhracat Vaziyeti: İstihsalin Arttırılması ve Rasyonalizasyonunu Temin Edecek Zirai ve İktisadi Teşekküllerin Kurulması ve Teşkilatlandırılması Etüdü", Rapor (Ankara, 1938), 15.

$14 \mathrm{Bu}$ açıdan, Zeytincilik Kanunu'nun yasama mantığı sonraki yıllarda (1945) yasalaşacak "Çiftçiyi Topraklandırma Kanunu" ile paralellik göstermektedir. Dönemin iktidarı, hegemonya kurmanın bir yolu olarak topraksız köylüleri ve küçük üreticileri yanına çekmek için bunun gibi farklı yeniden bölüşüm mekanizmaları işletmiştir. Bkz. Çağlar Keyder, Şevket Pamuk, "1945 Çiftçiyi Topraklandırma Kanunu Üzerine Tezler", Y̧apıt Toplumsal Araştırmalar Dergisi 8 (1985): 52-63; Faruk Birtek, Çağlar Keyder, “Türkiye'de Devlet-Tarım İlişkileri, 1923-1950", çev. Nur İmer, Birikim 22 (1976): 31-40. 
—başıboş yabani zeytin ağaçlarının bulunduğu alanlar — tamamen kültüre alınabilmiş ve mülklendirilebilmiş, "şenlendirilebilmiş" ne zeytin ve zeytinyağ üretiminde periyodisite (var y1lı-yok yılı farkı) "rasyonel" zeytinciliğin yapıld1ğ 1 diğer Akdeniz ülkelerindeki kadar kontrol altına alınabilmiştir.

2017 yılında Bornova Zeytincilik Araştırma Enstitüsü'nün hazırladığı “Türkiye Zeytincilik Sektör Raporu” Türkiye'de 2000'lerin ortalarından itibaren yaşanmakta olan zeytincilik seferberliği neticesinde zeytincilikteki mevcut durumu etraflıca değerlendirmektedir. Raporun sonuç kısmında yer alan sofralık zeytin ve zeytinyağ 1 sektörünün geliştirilmesi için listelenen tavsiyeleri 1938 yılında hazırlanan raporda sıralananlarla karşılaştırmalı olarak incelediğimizde, zeytinciliğin ıslahına yönelik önerilerin birçoğunun geçen yaklaşık 80 yıllık dönemde ciddi ölçüde değişmediğini görebiliriz. ${ }^{15}$ Genel olarak tarımsal üretime, daha özelinde zeytinciliğine dair politika önerilerinde üretim ve işleme sürecinde geleneksel yöntemler yerine modern tekniklerin kullanılması gerekliliği vurgulanmaktadır. İki metin arasındaki söylem farkı ise devlet-üretici ilişkilerinin iki dönemde nasıl düzenlendiğine dair farkı yansıtmaktadır. İlk dönemde zeytinciliğin sslahı doğrudan kamunun bir görevi olarak telakki edilirken, bugün için kamuya zeytincilik alanında faaliyet gösteren, ortak bir hedefi paylaşan ve ortak bir çıkarı gözeten "eşit" paydaşlar arasında düzenleyici bir rol çizilmiştir.

Türkiye'nin zeytinyağı dış ticareti, yıllık üretim miktarına bağlı olarak dalgalı bir seyir göstermektedir. Dünya piyasasında sabit bir yer bulabilmenin temel kuralı ürünü yıl boyunca düzenli bir şekilde raflarda bulundurabilmektir. Kalitedeki ve arzdaki süreklilik ülkesel bir marka yaratmak ve uluslararası piyasada yer bulabilmek için önemlidir. Bu nedenle ihracatçıların her yıl düzenli olarak mal bulabilecekleri bir sistemin tartışılması gerekmektedir. ${ }^{16}$

Tarımda kapitalist gelişme ve modernleşmenin tarihsel ve diyalektik bağlantısı Türkiye'de zeytinciliğin gelişimi üzerinden de düşünülebilir. Tarımda kapitalist üretim ilişkilerinin gelişmesi ve derinleşmesi ilkel birikimin koşullarının tarihsel olarak oluşması ve sürekliliği ile mümkün olabilmiştir. Bu anlamıyla tarımda kapitalist gelişme üreticilerin üretim araçlarından kopması, özel mülkiyetin kurumsallaşması, toprağın ve üretim araçlarının metalaşması gibi süreçlere paralel olarak, kapitalist üretim ilişkilerinin geleneksel üretim ilişkilerinin yerini alması veya geleneksel üretim örüntülerinin piyasa sistemine eklemlenmesi ile sermaye birikimi rejiminin tarımda kurumsallaşması olarak düşünülmelidir. Bu açıdan, tarımda kapitalist gelişmenin hem önkoşulu hem de sonucu olan üretici güçlerin gelişimi ve insan-doğa ilişkilerinin niteliksel değişimi aynı zamanda tarımda modernleşmenin tarihidir.

Zeytincilikte farklı dönemlerde gündeme gelen seferberlik süreçleri Cum-

15 Zeytincilik Araştırma Enstitüsü Müdürlüğü (ZAE), Türkiye Zeytincilik Sektör Raporu, İzmir (2017), 273-280, http://www.marmarabirlikakademi.com/ContentImages/SeminarFiles// SeminarFile_350b2b4e-6b39-4a25-b5f4-806363308dcc.pdf, erişim tarihi 22 Mayıs 2017.

16 ZAE, Türkiye Zeytincilik Sektör Raporu, 278. 
huriyet'in kurucu ethosu modernleşme ideolojisinin bu alandaki yansımasının tarihsel uğraklarıdır. Bu kapsamda Türkiye'de zeytincilik tarihi üzerine dönemsel bir inceleme bu yazının kapsamının dışındadır. Ancak modernleşme söylemi zeytinciliğe dair güncel pratiklerin beslendiği bir üst anlatı olması sebebiyle, iktidarın çelişkili zeytin siyasetinin çözümlenmesi ve zeytinciliğin son dönemde geçirdiği dönüşümün incelenmesi için açıklayıcıdır.

\section{0'lerdeki Zeytin Seferberliği Sürecinin Politik Ekolojisi ${ }^{17}$}

Bu doğrultuda 2000'lerde telaffuz edilen zeytincilik seferberliği ile Cumhuriyet'in kuruluş yıllarında başlatılan bu modernleşme atılımı bir süreklilik içinde düşünülmelidir. Zeytincilik seferberliği Türkiye'yi zeytincilikte (İspanya'nın ardından) dünyada ikinci ülke seviyesine getirmek hedefiyle planlanmaktadır. $\mathrm{Bu}$ hedef ilk olarak zeytin ağacı sayısının arttırılmasına işaret etse de zeytin üretiminde diğer ülkelerin çok gerisinde olan verimliliğin arttırılması ve zeytinyağ1 üretiminde geleneksel yöntemlerin modernleştirilmesi anlamına gelmektedir.

Küresel gıda rejiminde yaşanan gelişmeler gıda üretimi açısından yeni bir uluslararası iş bölümünü beraberinde getirmektedir. Uzun bir sürece yayılan bu dönüşüm merkez ülkelerin tahıl ve yağ bitkileri üretiminde ölçek ekonomisi ve üretim destekleri ile uzmanlaşmasını, çevre ülkelerin ise farklı zamanlarda uygulamaya konan neoliberal yapısal uyum programları sonucunda tarımda göreli avantaja sahip olabileceği, emek yoğun bir üretim gerektiren taze meyve ve sebzelerde uzmanlaşmasını doğurmuştur. Türkiye'de tarım alanlarının küçük ve parçalı yapısı, tarımsal nüfusunun görece fazlalığı, halen sulama ve mekanizasyonda yeterli altyapı düzeyine erişilememiş olması gibi gerekçelerle de desteklenerek, tarımsal yapının dönüşümü küresel iş bölümüne uygun olacak şekilde tahıl ağırlıklı bir üretimden ihracat odaklı yaş meyve ve sebze üretimine doğru bir yönelme şeklinde yaşanmaktadır. ${ }^{18}$ Türkiye tarımı açısından geleneksel sayılabilecek tütün, pamuk ve şeker pancarı gibi bazı ürünlerde üreticilerin üretimi sürdürme koşulları uygulanan politikalar sonucunda imkânsız hale gelmeye başlamıştır. Dünya Bankası gözetiminde 2001'de uygulamaya konan Tarım Reformu Uygulama Projesi (TRUP) kapsamında tarımda destekleme rejimi değişmiştir. 2008 yılında kaldırılan Doğrudan Gelir Desteği Sistemi'nin yanı sıra tarım ürünleri piyasasında piyasa rasyonalitesinin tesis edilmesi amacıyla artık-fazla üretimin yapıldı̆̆ı düşünülen ürünler için alternatifler belirlenip bölgesel farklılıklar ve şartlar göz önünde bulundurarak bir

17 Bu bölümde zeytinciliğin dönüşümüyle ilgili ortaya konan argümanlar referans verilen kaynakların yanında Boğaziçi Üniversitesi BAP fonu tarafından desteklenen ve Prof. Dr. Fikret Adaman tarafından yürütülen "Zeytin ve Zeytinyağı Hakkındaki Kamu Düzenlemelerinin Ekonomi-Politiği Üzerine Bir Çalışma" kapsamında yazar tarafından yapılan saha ziyaretlerindeki gözlemlere ve zeytincilik ile uğraşan kişilerle yapılan görüşmelere dayanmaktadır. Bkz. Fikret Adaman ve Orkun Doğan, "Zeytin ve Zeytinyağ 1 Hakkındaki Kamu Düzenlemelerinin Ekonomi-Politiği Üzerine Bir Çalışma", Yayınlanmamış Araştırma Raporu, Boğaziçi Üniversitesi BAP: 16C01P4, 2017.

18 Çağlar Keyder, Zafer Yenal, "Agrarian Change under Globalization: Markets and Insecurity in Turkish Agriculture", Journal of Agrarian Change 11, no. 1 (2011): 65-70. 
destekleme politikası oluşturulmuştur. Zeytin, iklim ve coğrafyanın izin verdiği bazı bölgelerde, geleneksel ürünlerin tasfiyesi sonucunda marjinalize olan üreticiler için alternatif bir ürün olarak düşünülmüştür. ${ }^{19}$

Zeytinciliğin modernleştirilmesi projesinin yeniden politik ajandaya dahil edilmesinin ötesinde, hükümet nezdinde zeytinciliğin desteklenmesinin başka sebepleri de vardır. Tarımsal yapının 2000'lerin başında uygulamaya konan neoliberal reformlarla dönüşümü çerçevesinde ve Avrupa Birliği'ne (AB) kat1lım süreci dahilinde tarım sektörünün Avrupa Ortak Tarım Politikası (OTP) ile uyumlulaştırılması kapsamında zeytin ve zeytinyağı tarım sektöründe stratejik bir sektör olarak belirlenmiştir. $A B^{\prime}$ ye üye ülkelerin tarım politikalarını siyasal ve ekonomik anlamda bütünleştiren OTP'nin temel amaçlarından biri tarım ürünleri piyasalarında arz-talep dengesini kontrol altında tutarak fiyat istikrarı sağlamak ve bu kısıt altında üretici gelirlerini arttırmaktır. Zeytin ve zeytinyağı piyasası özelinde de destekleme politikaları arz kontrolünü sağlamak ve üreticilerin gelirlerini arttırmak amacıyla tasarlanmıştır. Bu yıllarda OTP kapsamında uygulanan destekleme modeline göre zeytin üreticisi üye ülkelere $\mathrm{AB}$ ortak bütçesinden yapılan destekler, topluluğun zeytinyağı üretim hacmi, tahmini tüketim miktarı ve ihracat potansiyeli gibi unsurlar dikkate alınarak belirlenen "maksimum garanti edilmiş miktar" üzerinden belirlenmektedir. Türkiye'nin $\mathrm{AB}^{\prime}$ ye tam üyeliğinin gerçekleşmesi ve tarım politikalarının OTP kapsamında yeniden düzenlenmesi durumunda zeytin desteklerinden alacağı pay, Türkiye için tespit edilecek maksimum garanti edilmiş miktar, üyeliğin gerçekleştiği yıldaki zeytin ağacı sayısının sayısı oranında olacağı bilinerek, o zamana kadar zeytin ağacı sayısının mümkün olduğunca hızlı bir şekilde arttırılması hedeflenmiştir. ${ }^{20}$

Sertifikalı fidan ile yeni, kapalı zeytin bahçesi kuracak olan yatırımcılar için uygulanmakta olan destekleme yardımlarının 2005 yılında kayda değer oranda arttırılması tarım dışından gelen yatırımcıların zeytine yönelmesinde ve zeytin ağacı varlığının artmasında önemli bir etmen olmuştur. Ayrıca, bu yıllarda bazı devlet kurumları tarafından iklimsel ve coğrafi uygunluk aranmadan ihale yoluyla küçük ölçekli fidan firmalarından temin edilen zeytin fidanları sosyal yardım kapsamında fidan temin edemeyen üreticilere ücretsiz olarak dağıtılmıştır. Zeytin ağacı sayısında ve toplam zeytinlik alanların artmasında bir diğer önemli etken de Maliye Bakanlığı ve Orman Bakanlığı'nın uygulamaya geçirdiği “Özel Ağaçlandırma” projeleri olmuştur. Özel ağaçlandırma uygulamaları Cumhuriyet'in ilk yıllarında planlanan kamu arazilerindeki yabanilerin aşılatılarak bu arazilerin mülkiyetinin zeytinlerin bakımını üstlenen üreticilere devredilmesi projesinin neoliberal bir mantıkla yeniden yorumlanması olarak düşünülebilir.

Zeytincilik seferberliği kapsamında yukarıda aktarılan teşvik ve destekle-

19 Bülent Güner, Zeki Boyraz, M. Dursun Çitçi, “Tütüncülükten Zeytinciliğe Geçiş: Akhisar (Manisa) Örneği", Zeitschrift für die Welt der Türken/Journal of World of Turks 2, no. 1 (2010): 161-169.

20 "Bakan Eker: 170 Milyon Zeytin Ağacı Dikmeyi Hedefliyoruz", ANKA, https://www. haberler.com/bakan-eker-170-milyon-zeytin-agaci-dikmeyi-3203144-haberi/, erişim tarihi 25 Ekim 2018. 
me politikalarının zeytin ve zeytinyağı üretiminin, ihracatının ve tüketiminin arttırılması gibi hedefler açısından değerlendirilmesi bu yazının kapsamını aşmaktadır. Bu kısımda Türkiye'de 2000 sonrasında tarımsal yapının dönüşüm süreci ve zeytincilikte uygulanan reformlar paralelinde Anadolu coğrafyasında zeytin ağaçlarının konu olduğu devinim süreci politik, ekolojik ve ekonomik sonuçları itibarıyla ortaya konacaktır.

Türkiye'de tarımın neoliberal dönüşümü ve zeytincilik seferberliği olarak anılan sürecin kesişiminde zeytin ağacı varlığında son yıllarda önemli bir artış gözlemlenmektedir. 10 yıl önce yaklaşık 100 milyon olan ağaç sayısı bugün yaklaşık olarak 180 milyon mertebesine ulaşmıştır. ${ }^{21}$ Bu yıllarda zeytin ağacı sayısındaki artış ile zeytinlik alanların değişimini birlikte değerlendirdiğimizde toplam zeytin ağacı sayısındaki artış hızının zeytinlik alanlardaki artış hızından daha yüksek olduğu görmekteyiz. Bu da bize zeytinlik alanların genişlediğini ve yeni kurulan zeytin bahçelerinin daha yoğun bir dikim rejimi ile tesis edildiğini göstermektedir. Parçalı (farklı parsellerden oluşan) zeytin ağaçlarının daha dağınık bulunduğu geleneksel zeytinliklerden, birim alanda daha sık ve düzenli aralıklarla dikilen zeytin ağaçlarının olduğu modern zeytin bahçelerine doğru bir geçişin bu süreçte hızlandığı söylenebilir.

Zeytin ağacı sayısındaki artışı bölgesel olarak incelediğimizde zeytinciliğin geleneksel olarak yapıldığı bölgelerin dışında farklı zeytin üretim bölgelerinin de oluşmaya başladığını görmekteyiz. Yukarıda bahsedilen ürün yelpazesinin değişiminin bir örneği olarak 2000'lere kadar tütün üretiminin yapıldığ1 merkezlerden biri olan Manisa-Akhisar bugün zeytin ve zeytinyağı üzerinden bölgesel bir marka oluşturma gayretindedir. Ayrıca Doğu Akdeniz'de Mut, Çukurova, Kilis, Nizip gibi bölgeler bu süreçte zeytin üretiminde yeni merkezler olarak ön plana çıkmaktadır. ${ }^{22}$

Bölgesel farklılaşma aynı zamanda topografik bir dönüşüme işaret etmektedir. Türkiye'de Akdeniz'de zeytin üretiminin yapıldığı farklı coğrafyalarda olduğu gibi geleneksel zeytinlikler eğimli, teraslı arazilerde, genel olarak toprağın sığ ve verimsiz olduğu bölgelerde dağınık bir şekilde yayılmıştır. ${ }^{23}$ Akdeniz ikliminin hâkim olduğu makilik ve fundalıklarda yabani olarak gelişmiş delicelerin oluşturduğu zeytin ormanları özellikle Güney Ege'de halen birçok bölgede görülmektedir. Yeni yapılan dikimlerle oluşturulan bahçeler ise geleneksel zeytinliklere kıyasla daha geniş ve verimli taban arazilere (ovaya) kurulmuş, çitlerle yalıtılmış (kapalı) ve zeytin ağaçlarının sıralı dikime, sulamaya ve makineli hasada uygun olacak (modern) şekilde kurulmaktadır. Bu dönüşüm "zeytinin ovaya inmesi" olarak tarif edilmektedir. ${ }^{24}$ Geleneksel olarak zeytin üretiminin diğer tarımsal faaliyetlerin daha zor olduğu ikinci sınıf tarım arazilerinde yapıldığı düşünüldüğünde, bu değişim zeytin üretiminde farklı bir

21 Gümrük ve Ticaret Bakanlığı Kooperatifçilik Genel Müdürlüğü, “2017 Y1lı Zeytin ve Zeytinyağı Raporu" (Ankara, 2018).

22 ZAE, Türkiye Zeytincilik Sektör Raporu, 87-97.

23 Süleyman Aksu, “Türkiye'de Zeytinyağı Üretimi, Tüketimi ve Dışsatımı”, V. Teknik Kongre, Ocak 2000.

24 ZAE, Türkiye Zeytincilik Sektör Raporu, 125. 
üretim biçiminin ortaya çıktığının, aynı zamanda da tarımda gerileme olarak düşünülebilecek farklı bir üretim örüntüsüne geçilmekte olduğunun göstergesidir.

Bu dönüşüm ile zeytin üretiminde farklı üretici profilleri de oluşmaya başlamıştır. 2000 sonrasında alternatif ürün desteklemelerinden yararlanarak tarım sektörü içinde başka ürünlerden zeytine yönelen üreticiler olmuştur. Tarım içinden zeytine yönelen üreticiler açısından bu geçiş farklı gerekçelerle gerçekleşmiştir. Bazı geleneksel ürünleri üreten üreticiler için tarımsal dönüşümün seyri içinde ürünlerine pazar bulamama, üretim maliyetlerini karşılayamama gibi ekonomik sebepler zeytine geçişte öncelikli olurken, başka üreticiler için genç neslin farklı sebeplerle tarımsal üretimi bırakması, sürdürmek istememesi sonucu senelik bitkisel üretim için yeterli emek gücünün bulunamaması ve zeytin tarımının hasat dönemi dışında daha az emek yoğun bir üretimi mümkün kılması zeytin üretimine geçişte etkili olmuştur. ${ }^{25}$

Son yıllarda endüstriyel gıda sisteminin yol açtığı problemler ve işlenmiş gıdaların sebep olduğu hastalıklar tüm dünyada önemli bir gündem haline gelmiştir. Gıda adaletinin olmadığı bir sistemde açlık çözülemeyen bir sorun olarak kenarda dururken, üst sınıflar da sağlıklı beslenme için her an bir arayış içindedir. Akdeniz mutfağı ve diyetinin sağlıklı ve iyi gıdayı simgeleyen bir muhayyel olarak ortaya çıkması onun temel bileşeni olan zeytinyağına olan uluslararası talebi arttırmaktadır. Buna bağlı olarak Akdeniz kıyısında tarih boyunca var olan tüm medeniyetlerin yemek kültüründeki ortak değer olan zeytinyağı, son yıllarda geleneksel olarak tüketildiği coğrafyaların ötesinde de tercih edilmeye ve rağbet görmeye başlamıştır. ${ }^{26}$

$\mathrm{Bu}$ da zeytin ve zeytinyağı sektörünü kârlı bir yatırım olarak gören ve bu alana yönelen girişimcilerin sayısının artmasına sebep olmaktadır. Son yıllarda bu alana yönelik olarak desteklemelerin ve kredi ve hibe imkânlarının etkisiyle birçok yatırımcı zeytinyağı sektörüne yönelmiştir. Örneğin, uluslararası gıda rejimi ve iş bölümü çerçevesinde Türkiye'de üretilen zeytinyağlarının Ortadoğu pazarına açılmasıyla bu bölgelere ihracat yapan bazı firmalar ürün paletlerine zeytinyağını da eklemişlerdir. Bu firmalar daha çok sözleşmeli tarıma benzer şekilde bazı üreticileri doğrudan kendilerine bağlayarak veya küçük üreticilere fason üretim yaptırarak piyasaya dahil olmakta veya dikey entegresyon yoluna giderek hem zeytinlik hem zeytinyağı üretim tesis yatırımlarına girmekteler.

Tarım dışından zeytin sektörüne yönelen bir başka üretici profili olarak şehir yaşamından sıkılan, kırsalda dönemsel veya tamamen bir yaşam kurarak "hobicilik" şeklinde veya profesyonel olarak tarımsal bir faaliyet sürdürmek isteyen, bunu da iklimin uygun ve doğal güzelliklerin çok olduğu Batı bölgelerinde gerçekleştirmeyi arzu eden "yeni köylüler"den bahsedebiliriz. Bu kişiler için zeytinlik sahibi olmak, kendi zeytinyağını üretmek ve bunu markalı, pres-

25 Adaman ve Doğan, "Zeytin ve Zeytinyağı Hakkındaki Kamu Düzenlemelerinin Ekonomi-Politiği Üzerine Bir Çalışma", 36-37.

26 Savran, Kerem, vd. “Dünyada ve Türkiye'de Ham Tane Zeytin, Sofralık Zeytin ve Zeytinyağ Piyasası", Apelasyon Dergisi 30 (2016), http://apelasyon.com/Yazi/447-dunyada-ve-turkiyedeham-tane-zeytin-sofralik-zeytin-ve-zeytinyagi-piyasasi, erişim tarihi 20 Mayıs 2017. 
tij bir ürün olarak satmak veya hediye ekonomisi içerisinde değerlendirmek şehirden kıra yerleşmekte bir motivasyon kaynağı olabilmektedir. ${ }^{27}$

Yukarıda bahsedilen yeni üretici profillerinin dışında, tarımın ve zeytinciliğin dönüşümü ile zeytin ve zeytinyağ tedarik zincirinin işleme ve pazarlama aşamasında da yeni aktörler zincire dahil olmaktadır.

2000 yılında TRUP kapsamında çıkartılan Tarım Satış Kooperatifleri ve Birlikleri Hakkında Kanun, devlet-üretici arasındaki ilişkileri düzenleyen ve kamu maliyesi desteğiyle piyasaya doğrudan müdahale edebilen Tarım Satış Kooperatifleri ve Birlikleri'nin hazırlıksız bir şekilde (ve borçları ile) mali ve idari olarak özerkleşmesini hedeflemekteydi. Tarihsel olarak zeytinyağ 1 tedarik zincirinde önemli bir aktör olan Tariş (Tariş Zeytin ve Zeytinyağ Satış Kooperatifleri Birliği) bu özerkleşme sürecini yerelde üretici-üyeleri ile kurduğu ilişkiler ve kurumsal altyapısının sağlamlığı sayesinde diğer üretici birliklerine nazaran iyi yönetebilmiş ve zeytinyağı pazarında — kamunun mali desteği olmadan - diğer firmalarla rekabette önceki yıllara kıyasla pazar payı azalmakla birlikte ayakta kalmayı başarabilmiştir. ${ }^{28}$

Uluslararası gıda sisteminin neoliberal dönüşümünün bir dinamiği olarak ulus-ötesi şirketlerin uluslararası gıda tedarik zincirleri üzerinde kontrolleri artmaktadır. Bu durum, Türkiye'de son yıllarda zeytinyağı tedarik zincirinde de gözlemlenmektedir. Tarihsel olarak Tarım Satış Kooperatifleri Birliği olan Tariş ve Komili, Kristal, Kırlangıç gibi aile şirketlerinin ağırlığında oligopol bir yapıda olan resmi ulusal zeytinyağı piyasasının üst kısmında, satın alma ve birleşmelerle yoğunlaşma ve uluslararasılaşma görülmektedir. ${ }^{29}$ Bununla birlikte, son yıllarda "butik üretim" yapan yerel zeytinyağı firmaların toplam pazar payının artmasıyla piyasanın alt kısmında ise yerelleşme gibi bir dinamik eş zamanlı olarak görülmektedir. Butik üretim yapan firmalar zeytinyağının kimyasal, biyolojik ve duyusal olarak diğer bitkisel yağlardan ayrılan özelliklerine vurgu yaparak piyasada farklı bir değer sistemi içerisinde değerlendirilmesini amaçlamaktadır. Bu modelde ağacın bakımına, budamasına, işlenmesine, ürünün saklama koşullarına ve ticaretine yönelik bir dizi alternatif pratikler oluşturmaya çalışmaktalar.

Yukarıda ayrıca altı çizilmeye çalışıldığı gibi, zeytincilikte aktarılan gelişmeler tarımdaki dönüşüme bağlı olarak yeni üretim bölgelerinin ve böylece, bölgeler arasında bir rekabetin oluşmasına sebep olmuştur. Zeytin sektöründeki kapitalist gelişmeye bağlı olarak üretici profili değişmeye başlamıştır. Bölgeler arası üretim güçlerinde farklılaşmayla birlikte üretim ilişkilerinde ve mülkiyet rejiminde bir dönüşümün yaşandığı görünmektedir. ${ }^{30}$ Bu yeni üretim rejimi

27 Adaman ve Doğan, "Zeytin ve Zeytinyağı Hakkındaki Kamu Düzenlemelerinin Ekonomi-Politiği Üzerine Bir Çalışma", 29-30.

28 Adaman ve Doğan, "Zeytin ve Zeytinyağı Hakkındaki Kamu Düzenlemelerinin Ekonomi-Politiği Üzerine Bir Çalışma", 12-13.

29 Necdet Oral, Türkiye'de Tarımın Ekonomi-Politiği 1923-2013 (Ankara: Notabene, 2013), 159200.

30 Orkun Doğan, “Zeytin Ağacının Gölgesinde: Tarım ve Enerji Alanında 2023 Kalkınma Stratejileri", Toplum ve Bilim 138-139 (Aralık 2016): 96. 
aynı zamanda bir ekolojik rejime de işaret etmektedir. Zeytinyağı üretiminde ve ticaretinde uluslararası standartların geliştirilmesi, yeni üretim bölgelerinde daha yoğun bir üretim sürecinin benimsenmesi, özel ağaçlandırma projeleri ile kamu arazilerinin kiralanıp bu alanların zeytin plantasyonuna dönüştürülmesi, cins seçimlerinde coğrafi, iklimsel ve kültürel özelliklere dikkat edilmeden monokültür üretimin desteklenmesi gibi süreçlerin üretim ilişkileri, emek örüntüleri ve piyasadaki güç ilişkileri açısından etkilerine bağlı olarak politik ekonomik ve ekolojik sonuçları olmaktadır.

\title{
Zeytin Ağaçları Korkuyu Beklerken
}

\author{
“Güçlü bir el silkeledi beni sonra \\ Sanırım Tanrı́nın eliydi. \\ Sayamadım kaç ah döküldü dallarımdan. \\ Binlerce yeşil gözü olan bir zeytin ağacı gibi, \\ Çok şey görmüşüm gibi, \\ Ve çok şey geçmiş gibi başımdan, \\ Ah... dedim sonra \\ $\mathrm{Ah} !^{\prime \prime 31}$
}

Zeytin seferberliği sürerken, özellikle 2000'lerin ikinci yarısı itibarıyla, fark1 bölgelerde zeytinlik arazilerin çeşitli yatırım projeleri için acele kamulaştırıldığ1 ve zeytin ağaçlarının topluca kesildiği bir süreç başlamıştır. Bu süreç, Türkiye'de sermaye birikim rejiminin ve iktidarın kalkınma yaklaşımının kır mekânına etkilerinin bir yansıması olarak görülebilir. Neoliberal rasyonaliteye uygun olarak 2000 'lerin başından itibaren hayata geçirilen yasal düzenlemelerle kamunun stratejik sektörlerde üretimden çekilip piyasa kuran ve düzenleyen bir role bürünmesi inşaat, madencilik ve elektrik üretim ve dağıtım gibi alanların sermaye açısından önemli değerlenme alanları olması için bir ortam yaratmıştır. Küresel piyasa sistemi içinde dönemsel olarak yükselen ekonomilere yönelen sermaye akışı, Türkiye ekonomisinin istikrarlı ve yüksek büyüme performansı ve Türk lirasının göreli olarak değerliliği yüksek bütçeli projeler için gerekli olan finansmanın daha kolay bulunmasını getiriyordu. Yatırım ortamının sağlanmasının ve — sermaye için— cazibe merkezlerinin oluşturulmasının, yatırımın önündeki bürokratik engellerin kaldırılmasının, kamu politikalarını ve yürütmenin icraatlarını belirleyen temel ilke haline gelmesiyle yasal mevzuatın buna uygun olarak yeniden düzenlenmesi gerekti. İhale kanunları, elektrik piyasası kanunları, madencilik yönetmeliği ve çevre koruma mevzuatı bu süreçte ihtiyaca uygun olarak birçok defa değiştirildi. Tarımdaki çözülmenin tetiklediği işsizliğin ücretlerdeki baskısı ve iş yasalarında düzenlemelerle yaygınlaşan taşeron ve esnek çalışma rejimi ile sermayenin emek üzerinde tahakkümü artarken, kırda ve kentte yeni çitlemeler ile sermaye için yeni değerlenme alanları yaratılıyordu. Bu süreç kentlerde kentsel dönüşüm ve soylulaştırma projeleri ile yeni rant alanları açılması ve kamu arazileri ve binalarının özelleştirilmesi üzerinden yaşanırken kırda meraların, ormanların, kıyıların veya

31 Didem Madak, "Ah'lar Ağacı", Ah'lar A ̆̆acı içinde (İstanbul: Metis, 2012), 13-33. 
tarım alanlarının kullanım amacının değiştirilerek yatırım projelerine açılması şeklinde gerçekleşmektedir.

1990'larda, turizm sektörünün ekonomik büyüme adına motor olarak görüldüğü yıllarda, Ege ve Akdeniz kıyılarındaki zeytinliklerin imara açılması ve yok edilmesi turizm teşvikleri ve bu alandaki özel sermaye yatırımları ile sayıları artan turistik tesis ve yazlık siteler ile gündeme gelmekteydi. 2000'lerin ilk yarısında kalkınma planlarında madencilik sektörü ön plana çıkmaktaydı. Kaz Dağları'ndaki altın madenciliği ve inşaat sektörünün büyümesiyle artan talebi karşılamak için yurt genelinde sayıları hızla artan taş ocaklarıyla bağlantılı olarak zeytin ağaçlarının tahribatı gündeme gelmekteydi. 2000'lerin sonundan itibaren ise enerji üretiminde yerli kaynakların payının arttırılmas1 ve kömür üretiminin ve kömürle çalışan termik santrallerin teşvik edilmesi ile bu kez zeytinliklerin farklı enerji santrali projeleri için kamulaştırıldığı ve tahrip edildiği bir süreç yaşanmaktadır. Tüm bu süreç boyunca, zeytin üretiminin yapıldığı bölgelerde, kent merkezlerinin büyümesine ve kentsel dönüşüm projelerine bağlı olarak da zeytinliklerin imara açılması ve zeytin ağaçlarının konutlaşma sebebiyle sürgün edilmesi söz konusudur.

Öte yandan zeytin ağaçlarının tahrip edilmesi sadece farklı sektörlerdeki yatırım projeleri sebebiyle ve illâki —yasal veya fiili- bir zor yoluyla gerçekleşmemektedir. Zeytin üreticileri de bizatihi başka bir ürün üretmek amacıyla veya tarım dışı yatırımlar için kullanılmak üzere mülkleri olan zeytinliklerdeki zeytin ağaçlarını sökmek yoluna gidebilmektedir. Bazı bölgelerde, hatalı destekleme politikası sebebiyle o bölgenin iklimine ve ekolojik şartlarına uygun olmayan cins zeytin fidanlarının dikilmesi sebebiyle bu bölgelerde yıllar içinde anomali yaşayıp büyüyemeyen zeytin ağaçlarının bahçe sahipleri tarafından kesildiği bilinmektedir. Medyaya da yansıyan bazı vakalarda ise üreticilerin zeytin ve zeytinyağı üretiminden hak ettikleri ölçüde kazanç sağlayamadıkları gerekçesiyle zeytin ağaçlarını sökmek zorunda kaldıkları anlaşılmaktadır.

Yukarıda sayılan zeytin ağaçlarının konu olduğu ekolojik tahribatlar, yasal veya yasal olmayan kesimler Zeytincilik Kanunu'nun yürürlükte olduğu süreçte yaşanmaktadır. Her ne kadar yasal koruma ile ilgili hükümler birçok vakada zeytin ağaçlarının kesilmesinin önüne geçemese de koruma hükümlerinin yasaya eklendiği 1996 yılından günümüze kadar yerel çevre mücadeleleri açısından çok önemli bir dayanak noktası ve meşruiyet zemini olmuştur. Farklı yatırım projeleri ile zeytinliklerin çakıştı̆̆ı ve ihtilafın söz konusu olduğu vakalarda, acele kamulaştırma kararlarının, Çevresel Etki Değerlendirme (ÇED) olumlu raporunun ve/veya projenin iptali için açlan hemen her davada, zeytinlik alanların daraltılamayacağını ve yakın çevresine zeytin ağaçlarının gelişmesine engel teşkil edebilecek tesislerin yapılamayacağını hükmeden kanunun 20. maddesi dava dosyalarında iptal gerekçesi olarak öne sürülmektedir. Mahkemeler de çoğu durumda bu hükme dayanarak projeler hakkında yürütmeyi durdurma veya iptal kararları vermektedirler. Hükümet bu aşamada öncelik verdiği belirli projelerde ve projenin hayata geçirilmesinin zeytinlik mevzuatına takıldığı vakalarda, torba kanun ile dolaylı olarak veya kanun hükmünde kararnameler yoluyla doğrudan, engel olarak gördüğü bu yasal mevzuatı aşma 
yoluna gitmektedir. Belirli durumlarda projeyi üstlenen firmalar da ekonomik ve politik güçleri ölçüsünde fiili olarak bu hükümleri görmezden gelebilmektedir.

Zeytinlik alanlara yasa düzeyinde koruma getiren mevzuatın yatırımları yavaşlatması veya sekteye uğratması gerekçesiyle hükümet tarafından değiştirilmesi 2000'lerin başından bu yana birçok defa gündeme gelmiştir. Tasarılarda, mevcut yasada koruma hükümlerinin olduğu maddeye eklenmesi planlanan istisna hükümleriyle kamu yararı kararı alınan yatırımlar için koruma hükümlerinin işletilemeyeceği bir düzenleme yapılmak istenmektedir. Yatırım ortamının iyileştirilmesi veya bürokrasinin azaltılması gerekçeleriyle öne sürülen mevzuat değişikliği önerileri, toplumsal muhalefetin mücadeleleri sonucunda bugüne kadar her seferinde hükümet tarafından geri çekilmiştir. Ancak hükümet içerisinde bahsi geçen sektörler ile ilgili bakanlıkların ve bu alanlardaki çıkar gruplarının çevre mevzuatında ve daha özelinde zeytinlik mevzuatındaki koruma hükümlerinin yatırımlar lehine gevşetilmesi hususunda baskısının devam ettiği bilinmektedir.

Kamu harcamalarının ve altyapı yatırımlarının yönlendirilmesi, sektörel teşvikler, desteklemeler veya hibeler gibi yeniden dağıtım mekanizmalarının planlanması sınıf içi ve sınıflar arası ittifakların ve rekabetin görünür olduğu, hegemonya mücadelesinin somutlaştığı alanlardır. Bu mücadelenin devlet yönetimi düzlemine bir yansıması vardır. Bu da bürokrasi içerisinde bakanlıklar arası örtük bir hiyerarşiye işaret etmektedir. Bu mücadelenin seyri iktidarın ekonomi programlarında, kalkınma stratejilerinde ve yatırım ve ticaretin kurallarını belirleyen yasa ve yönetmeliklerde hayata geçirdiği düzenlemeler üzerinden takip edilebilir. Tarıma verilen önemin azalmasına ve tarımın ekonomi içerisindeki payının gitgide düşmesine paralel olarak, tarımdan sorumlu bürokrasi bu hiyerarşi içerisinde gerilere düşmekte, otonom politika belirleme kapasitesi kalmamaktadır. Bir önceki bölümde etraflıca tartışıldığı üzere, 2000'lerin ilk yarısı itibarıyla farklı çıkar gruplarını temsil eden zeytincilik sektörünün çalışmaları sonucunda iktidar tarım desteklemeleri içinden zeytincilik alanına yönelttiği payı arttırmış, farklı ihracat teşviklerini yürürlüğe koymuş, yeni dikimler ve aşılamalar yapılması ve zeytinlik alanların genişlemesi için farklı bakanlıklar üzerinden çalışmalar başlatmıştır. Bugün sektörün farklı paydaşlarının değerlendirmelerine baktığımızda aradan geçen zamanın sonunda bu heyecanın sürdüğ ünü söylemek güç olacaktır. Zeytincilik sektörünün belirli bir politikanın uygulamaya geçirilmesi veya sektörün çıkarına aykırı olabilecek bir düzenlemenin geri çekilmesi hususunda iktidarı ikna kapasitesinin düştüğünü söyleyebiliriz.

Zeytincilik sektörünün zeytin ağaçlarının korunması hususunda ekoloji hareketi ile ittifakı bugüne kadar farklı sektörlerden gelen aksi yöndeki kuvveti nötrleyebilmiş ve koruma mevzuatının yürürlükte olduğu statükoyu korumayı başarmıştır. Önümüzdeki süreçte de, zeytin ağaçlarının devinimi açısından önemli olan zeytinlikleri koruyan mevzuatın akıbeti bu politik mücadelenin seyrine bağlı olarak gelişecektir. 


\title{
Sonuç yerine: Zeytinin Müşterekler Siyasetine Dair Bir Önerme
}

\author{
"Şelaleye \\ Düşmüştür \\ Zeytinin dalı; \\ Celaliyim \\ Celalisin \\ Celali.." ${ }^{32}$
}

Bu çalışmada Akdeniz kültür dünyasının karakteristik bir öğesi olan, barış ve ölümsüzlüğü sembolize eden zeytin ağaçlarının Türkiye'de kalkınma, tarım ve çevre politikalarını belirleyen farklı yönleri ve yoğunlukları olan kuvvetlerin-güçlerin kesişiminde, parçası oldukları hegemonya mücadelesi dahilinde konu olduğu devinim incelenmiştir. Devinim sözcüğü bu yazıda zeytin ve zeytin ağaçları odak alınarak kavramsallaştırılmıştır. Zeytin ağaçlarının insani faaliyetler sonucunda yerinden edilmesinin ötesinde, zeytinin siyasetinin, ekonomisinin ve ekolojisinin toplumsal değişim içerisinde geçirdiği dönüşüm eleştirel olarak incelenmiştir. Üretim ilişkilerinde meydana gelen değişime paralel olarak insanın doğayla kurduğu ilişkinin dönüşümünün analizi devinimin tartışıldığı soyutlama düzlemidir.

Zeytincilik seferberliği 2000'lerde farklı ekonomik ve politik gelişmelerin kesişiminde zeytinciliğin neoliberal politikalar sonucunda dönüşümü ve kapitalist üretim ilişkilerinin zeytin ve zeytinyağı üretiminde derinleştiği çatışmalı bir süreç olarak değerlendirilebilir. Zeytin ve zeytinyağı üretiminde kapitalist piyasa ilişkilerinin derinleşmesi ile zeytinyağı, zeytin ağaçları ve zeytinliklerin metalaşması ve piyasalaşması süreci hızlanmaktadır. Zeytincilik bu sürecin sonunda sermaye birikimi açısından bir eşdeğerlik düzlemine indirgenerek sermayenin değerlenme hızına ve temellük edilecek artık değer oranlarına göre diğer yatırım opsiyonları ile kıyaslanabilir olmaktadır. Bu da zeytin ağaçlarını ve zeytinliklerin metalaşmasını derinleştiren, sermayenin yeniden üretimini mümkün kılan değer düzlemidir. Bu düzlemde zeytin ağaçları veya zeytinlikler toplumsal, kültürel ve ekolojik değerlerinden soyutlanarak veya tüm sembolik değerleri mübadele değerine indirgenerek bir termik santralle, bir turizm tesisiyle, bir golf sahası veya bir yazlık ile kıyaslanabilir olmaktalar. Bu kıyaslamada da maalesef terazinin öteki kefesi ağır basmaktadır.

Geleneksel zeytin üreticileri açısından oyunun kurallarının yeniden belirlendiği, bu geçişe ayak uydurabilenlerin, yeni piyasa şartlarına uyum sağlayabildiği ölçüde üretimi sürdürebildiği; aksi halde marjinalize olarak zeytin üretiminden kopmak zorunda kaldığı ve zeytin ağacının gölgesinden uzaklaştığı bir süreç yaşanmaktadır. Benzer bir uyum ve elenme süreci zeytin ağaçları ve zeytinlikler için geçerlidir. Zeytin ağaçları estetik ve kültürel özelliklerini piyasa diline tercüme edebildiği ölçüde ekolojik manzaranın bir öğesi olarak kalabilmektedir. Modern zeytinlikler hayvanlardan ve diğer doğa bileşenlerinden yalıtılıp zeytin ağacının verimini maksimize edecek şekilde uygun girdi ile

32 Cemal Süreya, “Kısa Türkiye Tarihi”, Sevda Sözleri içinde (İstanbul: YKY, 2013), 222. 
buluşabilirse ve doğru işlenebilirse ekonomik olarak sürdürülebilir olacaktır.

Zeytincilik kanununda değişiklik önerilerinde taraf olan sermaye ve bürokrasinin farklı aktörleri arasındaki çatışma ve ittifaklar, sermaye grupları ve sektörler arasındaki sınıf mücadelesi ve güç ilişkilerine bağlı olarak hiyerarşinin kurulduğu bir müzakere alanı olduğunu bizlere göstermektedir. Devletin dönemsel olarak sektörler arası öncelikleri ve bunların tezahür ettiği kalkınma stratejileri sermaye birikim sürecinde ortaya çıkan krizlerin iktidar nezdinde nasıl yönetildiğinin bir göstergesidir. Çevre mevzuatındaki değişiklikler görünürde iktidarın tüm toplumun yararı için ekonomik büyümenin sağlaması amacıyla başvurduğu çeşitli adımlar olarak ifade edilse de, aslında hegemonya mücadelesinin bir sonucudur.

Zeytincilik kanununda değişiklik önerilerinde taraf olan sermaye ve bürokrasinin farklı grupları arasındaki çatışma ve ittifaklar göstermektedir ki mülkiyeti ve kullanımları vatandaşlar arasında ihtilaf oluşturabilecek ovalar, ormanlar, meralar, kıyılar, nehirler, denizler ve zeytinlikler gibi müşterek varlıkların devlet nezdinde idaresi ve hukuki statüsü bu anlamıla hâkim üretim tarzının ve toplumsal güç ilişkilerinin yansıdığı bir mücadele alanıdır. Bu açıdan çevre mevzuatının yatırım ortamını iyileştirmek ve yatırımcıların karşılaştıkları bürokrasiyi azaltmak amaciyla yeniden düzenlenmesinde öne sürülen kamu yararı kavramı üstüne düşünmek gerekir. Kamu yararı bu bağlamda hukuki bir kavram olmaktan çıkarak iş yapan bir kuvvet haline gelmekte ve materyal düzlemde belirgin etkiler doğurmaktadır. Liberal hukukun yasa mantığında özel çıkara karşı kamunun "müşterek" çıkarını gözeten bir kavram iken neoliberal devlet retoriğinde özel mülkiyetin, yasanın, siyasal ve ekonomik alanın sermaye lehine dönüştürülmesinin bir ifadesi haline gelmektedir.

Sermayenin mantığı zeytin ağacını onunla var olan diğer bütün aktörler tarafından atfedilen özelliklerinden ve anlamlarından sıyırarak genel eşdeğerlilik düzlemine, (ekonomik) değer biçimine indiriyor. Bu soyutlama, değersizleştirme ile birlikte hangi zeytin ağacının desteklenebilir, hangi zeytin ağacının korunabilir ve hangi zeytin ağacının feda edilebilir olacağı piyasa rasyonalitesine bırakılıyor. Bu hareket karşısında farklı coğrafyalarda zeytin ağaçlarına dair uzun yıllar boyunca kurulan anlam dünyasına özgü gerek piyasa sistemi içinden, gerekse bu genişlemeye karşı hareketler ortaya çıkıyor.

2014'te Yırca'da başlayan zeytin nöbeti, takip eden zamanlarda zeytin üretiminin yapıldığı farklı bölgelerde, örneğin Tire'de, Sütçüler'de, Gülpınar'da, Amasra'da, Orhanlı'da, Aliağa'da, Balıklıova'da planlanan enerji ve maden projelerinin yol açtığı yaşam alanı mücadelelerinde kendi özgün koşulları içinde yeniden ortaya çıkmıştır. Bugün de zeytin nöbetini, Aydın'da Kızılcaköy’de yerleşim yerlerine, birinci sınıf tarım arazilerine ve zeytinlik bahçelerine yakın bir konumda yapılması planlanan jeotermal enerji santraline ve bu proje kapsamında yapılacak sondaj kuyuları ve iletim hatlarına karşı çıkan bölge halkı, üreticiler ve ekoloji örgütleri sürdürmektedir.

Kırdaki güncel neoliberal çitleme pratiklerine karşı farklı bölgelerde zeytin nöbetleri sürerken, AKP'nin farklı zamanlarda gündeme getirdiği Zeytincilik Kanunu ile ilgili yasa tasarılarına karşı da zeytin üretiminin yapıldığı bölge- 
lerde ve Meclis'te farklı tarzda nöbetler organize edilmekteydi. 2014'te elektrik piyasası ile ilgili çıkartılan yasa kapsamında Zeytincilik Kanunu'nda yapılmak istenen malum değişikliklerin geri çekilmesi için başlatılan ve internet üzerinden yaygınlaştırılan "Zeytin Hayattır" adlı imza kampanyasına bir sene içinde 200 binden fazla insan imza vererek destek oldu. Bu desteğin oluşmasında aynı yıl Yırca'da yaşanan olayların kamuoyunda geniş yankı bulmasının payı büyüktü. Bu imza kampanyası 2016 ve 2017 yıllarında yasa değişikliklerinin yeniden Meclis gündemine taşınması üzerine "Türkiye'nin zeytinliklerinin ölüm fermanına hayır!" başlığıyla yeniden dolaşıma girdi. İmza metninde zeytinin kültürümüzün "ortak değeri" olduğu vurgulanarak, mevcut koruma yasasının hükümetin önerdiği şekilde değiştirilmesi halinde zeytinliklerimizin "madencilerin, enerji şirketlerinin, yol müteahhitlerinin ve inşaat devlerinin arka bahçesi" olacağ1 ve "hepimizi besleyen, yüzlerce aileyi doyuran toprakların birer şantiye, zehir depolama sahası" haline geleceği ifade edilmekteydi. Halen daha imzaya açık olan kampanyaya destek verenlerin sayısı 300 bini aşmış durumda ve yasayla ilgili gündeme gelen her öneride destekçi sayısı artmaktadır.

Farklı yerel bölgelerde sermayenin zeytinlik çitlemelerine ve zeytin ağaçlarını tahrip etme pratiklerine karşı mücadele eden yaşam savunucuları ile Zeytincilik Kanunu ile ilgili düzenleme önerilerine karşı farklı zamanlarda bir araya gelen toplumsal muhalefetin özneleri farklı politik düzlemlerde konumlansa da, sınıfsal kompozisyon ve mücadele biçimleri olarak ayrışsalar da, AKP'nin neoliberal zeytin siyasetinin karşısında birbirlerine omuz vermekteler. Yerel mücadeleler, Zeytincilik Kanunu'nu mevcut haliyle korumaya ve dolayısıyla zeytin ağaçlarını savunmaya çalışanların taleplerinin görünür olması ve kamuoyu nezdinde karşılık bulmasına aracılık ederken; Zeytincilik Kanunu'nun maden, enerji ve inşaat sektörü temsilcilerinin talep ettiği şekliyle değiştirilmesine engel olanlar, zeytin ağaçlarını, zeytinliklerini savunanların mücadelesine yasal ve meşru bir zemin kazandırmaktadır. Ancak savunma pozisyonunda olan ve artan otoriterleşmeye bağlı olarak hareket alanı daralan farklı düzeydeki bu siyasetlerin zeytin ağacını ve onun temsil ettiği tüm değerleri korumak için müşterek ve alternatif bir zeytin siyasetini tahayyül etmeleri gerekmektedir.

Sermayenin küresel düzeyde yoğunlaşan güncel çitleme pratiklerine karşı mücadele edenler için ortak ilke olarak düşünülebilecek müşterekler zeytin ağaçları ve zeytinlikleri savunanlar için nasıl bir siyaset açılımı sağlayabilir? Ekoloji hareketi, yerelde çevre ve yaşam alanı mücadeleleri ile ekoloji siyasetini ilişkilendirecek kanalları yaratmanın yollarını arar. Zeytin ve zeytin ağacı bu anlamda bir rabıta olarak düşünülebilir. Bugün sermaye birikim rejimindeki tercihlere bağlı olarak kalkınmada öncelik verilen inşaat, enerji ve madencilik projeleri Türkiye kırsalını ve kır yaşamını dönüştürmektedir. Zeytin ağaçları bu dışlayıcı, otoriter ve adaletsiz kalkınma pratiklerine itirazın bir aracı olma potansiyeli taşımaktadır.

Sermaye birikimini sürdürülebilir kılarken doğa ve toplum arasındaki metabolik yarılmayı derinleştiren, birikim krizlerine çözüm olarak daha yoğun bir şekilde doğayı ve emeği temellük eden, metalaştıran ve değersizleştiren bu büyüme rejimine ve kalkınma yaklaşımına karşı söylem ve pratikler üretmek 
derdinde olan bir siyasi proje için zeytin ağacı bir simge olarak seçilebilir. Bu hususta zeytin ağaçlarını ve zeytinlikleri bir müşterek olarak düşünmek, onları müşterekleştirme siyasetinin konusu haline getirmenin üstüne düşünmek gerekir. Müşterekleştirme siyasetinin önerdiği, zeytin ağacının kültürel olarak taşıdığı anlama atıfla onları ortak bir varlık, ortak bir nesne ve ekolojik bir müşterek olarak tanımlayarak onları tahrip edecek pratikler karşısında ortak bir zemin, bir savunma hattı kurmak değildir sadece. Zeytin ağaçlarını toplumsal metabolizmanın bir parçası olarak görerek, alternatif toplumsal ilişkilerin ve ona uyumlu bir mekân-ekoloji yaklaşımının geliştirilebileceği bir deney alanı olarak düşünülebilir. Bu halihazırda tehdit altında olan zeytinliklerle ilgili olarak ortak kullanım pratiklerinin veya ortak mülkiyet haklarının yeniden tahayyülü gibi teknik bir müdahale anlamına gelmemelidir. Zeytin ağaçları ve zeytinciliğe dair toplumsal ilişki üretimi olarak müşterekleştirme, zeytinliklerin kültürel, tarımsal, ekolojik, hukuksal statüsüne dair, zeytin ve zeytinyağı üretiminin toplumsal rolüne dair müşterek amaçlar tanımlamak, insanları ve mekânları bu amaçlar etrafında organize etmek ve diğer alanlardan beslenen veya diğer siyasetleri besleyecek alternatif ekolojik-toplumsal ilişkileri denemek olarak kavramsallaştırılabilir.

Geçmişten bugüne Türkiye'de zeytin ve zeytinyağı üretimine dair kolektif çabaları ve kooperatif girişimlerini, zeytin ağaçlarının tahribatına karşı yürütülen yerel mücadeleleri ve zeytinliklerle ilgili yasal mevzuatın düzenlenmesi üzerinden giden toplumsal mücadeleyi düşündüğümüzde zeytin, zeytin ağacı ve zeytinlikler üzerinden yürütülen siyasette önemli bir birikimin ve bunun toplumsal bir karşılığının olduğunu görüyoruz. Mevcut toplumsal ve ekolojik sömürü ve tahakküm ilişkilerini yeniden üretmeyen daha adil bir toplumsallaşmanın denemelerini hayata geçirmek için bu birikimleri bir araya getirmek ve birbirinden nasiplenmelerini sağlamak gerekmektedir ve açıktır ki zeytin ağacı yeniden top(ar)lanma ve alternatif bir tahayyül için müşterek bir tartışmayı başlatmak adına bizlere bir gölge sunmaktadır.

\section{Kaynakça}

Adaman, Fikret, Orkun Doğan. "Zeytin ve Zeytinyağı Hakkındaki Kamu Düzenlemelerinin Ekonomi-Politiği Üzerine Bir Çalışma”. Yayınlanmamış Araştırma Raporu. Boğaziçi Üniversitesi BAP: 16C01P4, 2017.

Aksu, Süleyman. “Türkiye'de Zeytinyağı Üretimi, Tüketimi ve Dışsatımı”. V. Teknik Kongre, Ocak 2000.

“Bakan Eker: 170 Milyon Zeytin Ağacı Dikmeyi Hedefliyoruz". ANKA. https://www. haberler.com/bakan-eker-170-milyon-zeytin-agaci-dikmeyi-3203144-haberi/. Erişim tarihi 25 Ekim 2018.

Birtek, Faruk, Çağlar Keyder. “Türkiye'de Devlet-Tarım İlişkileri, 1923-1950”. Çeviren Nur İmer. Birikim 22 (1976): 31-40.

Claval, Paul, Colette Jourdain-Annequin. "For Whom the Mediterranean Sea is 'Our Sea'?". Athens Journal of Mediterranean Studies 3, no. 2 (2017): 99-120.

Damar, Arif. "Her Gün Yaşamak". Yoksulduk Dünyayı Sevdik içinde, 94. İstanbul: Kırmızı Yayınları, 2007. 
Delamont, Sara. Appetites and Identities: An Introduction to the Social Anthropology of Western Europe. Londra: Routledge, 1995.

Doğan, Orkun. “Zeytin Ağacının Gölgesinde: Tarım ve Enerji Alanında 2023 Kalkınma Stratejileri". Toplum ve Bilim 138-139 (Aralık 2016): 84-106.

Gümrük ve Ticaret Bakanlığı Kooperatifçilik Genel Müdürlüğü. “2017 Y1lı Zeytin ve Zeytinyağ1 Raporu". Ankara, 2018.

Güner, Bülent, Zeki Boyraz, M. Dursun Çitçi. “Tütüncülükten Zeytinciliğe Geçiş: Akhisar (Manisa) Örneği". Zeitschrift für die Welt der Türken/Journal of World of Turks 2, no. 1 (2010): 161-186.

Han, Lixin. "Marxism and Ecology: Marx's Theory of Labour Process Revisited". Eco-socialism as Politics içinde, derleyen Qingzhi Huan, 15-31. Dordrecht: Springer, 2010.

Hehn, Viktor. Zeytin, Üzüm ve İncir: Kültür Tarihi Eskizleri. Çeviren Necati Aça. Ankara: Dost Kitabevi Yayınları, 1998.

Keyder, Çağlar, Şevket Pamuk. "1945 Çiftçiyi Topraklandırma Kanunu Üzerine Tezler". Yapıt Toplumsal Araştırmalar Dergisi 8 (1985): 52-63.

Keyder, Çağlar, Zafer Yenal. “Agrarian Change under Globalization: Markets and Insecurity in Turkish Agriculture". Journal of Agrarian Change 11, no. 1 (2011): 60-86.

Kenyon, Kathleen M., E. J. Moynahan ve J. D. Evans. “The Olive in the Mediterranean: Its Culture and Use [and Discussion]". Philosophical Transactions of the Royal Society of London. Series B, Biological Sciences 275, no. 936 (1976): 187-196.

Madak, Didem. "Ah'lar Ağacı". Ah'lar Ağacı içinde, 13-33. İstanbul: Metis, 2012.

Oral, Necdet, Türkiye'de Tarımın Ekonomi-Politiği 1923-2013. Ankara: Notabene, 2013.

Savran, Kerem, vd. “Dünyada ve Türkiye'de Ham Tane Zeytin, Sofralık Zeytin ve Zeytinyağ1 Piyasası". Apelasyon Dergisi 30, 2016. http://apelasyon.com/Yazi/447dunyada-ve-turkiyede-ham-tane-zeytin-sofralik-zeytin-ve-zeytinyagi-piyasasi. Erişim tarihi 20 Mayıs 2017.

Süreya, Cemal. “Kısa Türkiye Tarihi”. Sevda Sözleri içinde, 222. İstanbul: YKY, 2013.

T.C. Ziraat Vekaleti. "Zeytincilik, Ziraat, İstihsal ve İhracat Vaziyeti: İstihsalin Arttırılması ve Rasyonalizasyonunu Temin Edecek Zirai ve İktisadi Teşekküllerin Kurulması ve Teşkilatlandırılması Etüdü”. Rapor. Ankara, 1938.

Tekeli, İlhan. “İzmir Tarihi'nin İçine Yerleştirilebileceği Bir Akdeniz Üst Anlatısı Üzerine”. Akdeniz Tarihi, Kültürü ve Siyaseti “Çoğulluğu ve Farklılığı İçeren bir Birlik Özlemi" Sempozyumu Bildirileri içinde, derleyen Alp Yücel Kaya vd., 139-199. İzmir: İzmir Akdeniz Akademisi, 2016.

Toussaint-Samat, Maguelonne. A History of Food. John Wiley \& Sons, 2009.

Ünsal, Artun. Ölmez Ağacın Peşinde: Türkiye'de Zeytin ve Zeytinyağı. İstanbul: Yapı Kredi Yayınları, 2003.

W. V. Harris, "The Mediterranean and Ancient History". Rethinking the Mediterranean içinde, derleyen W. V. Harris, 1-38. Oxford: Oxford University Press on Demand, 2005.

Zeytincilik Araştırma Enstitüsü Müdürlüğü (ZAE). Türkiye Zeytincilik Sektör Raporu, (İzmir, Zeytincilik Araştırma Enstitüsü Müdürlüğü, 2016). http://www. marmarabirlikakademi.com/ContentImages/SeminarFiles//SeminarFile_350b2b4e6b39-4a25-b5f4-806363308dcc.pdf. Erişim tarihi 22 Mayıs 2017. 